\title{
Developing Student's Key Competencies through Cooperation with Enterprises
}

\author{
$R$. Dušek ${ }^{1, *}$ \\ *Corresponding author: dusek@mail.vstecb.cz. \\ ${ }^{1}$ VŠTE, České Budějovice, Czech Republic
}

\begin{abstract}
The aim of this paper is to describe proposal of the two semester course inspired by projectbased learning methods that could be applied to develop students' key competencies. Proposed method should be considered especially by university for business and economics, because its purpose is to integrate and develop competencies of final-year university students through working on specific projects in the areas of trade, marketing, economics or tourism. Project topics should be specified by various enterprises that are interested in cooperation with universities, so the course topics will be connected to business practice.
\end{abstract}

Keywords: competence approach, high education, cooperation with enterprises.

\section{Introduction}

The actual labour market requirements are no longer based only on theoretical or expert knowledge, but especially on higher level of key competencies. They can be defined as a generic complex of knowledge, values and attitudes, but primarily life skills such as $[1,2]$ :

a) problem solving,

b) ability to communicate effectively,

c) collecting and analysing information,

d) ability to work independently,

e) leadership,

f) creativity,

g) ability to cooperate effectively,

h) lifelong learning.

These competencies allow individuals to act adequately and efficiently within the various professional and personal life situations. They represent and incorporate a wide range of long term qualifications and requirements for a flexible response to the changing labour market demands and they also ensure maximum performance in the defined tasks [3].

Key competencies are behavioural, so if students have certain basic individual capabilities, their competencies can be developed throughout higher education. So, their further well managed development should be in the interest of those universities that want their graduates to be successful on the labour market, which should be very important especially for university for business and economics $[4,5]$.

The next step is to find and implement suitable approach enabling students to develop such key competencies. There are plenty of methods that have been proven to help in that, for example case studies [6], business simulation games [7, 8] or project-based learning methods [9]. The last mentioned options is widely considered as the most suitable method for students' key competencies development. This approach can be characterized by creating the students' research teams to work individually on long-term projects, which are connected to business practice and are designed to solve the actual business problems and cases $[10,11]$.

\section{Methods}

The aim of this paper is to present draft of the course that allows to develop students' key competencies through cooperation with enterprises. The course structure use as a basis the project-based learning methods. It is intended mainly for business and economics universities.

The structure of the course was inspired by various studies focused on implementing of effective competency and project-based learning methods [12-15], but it was adapted to the local conditions of the Czech labour market requirements.

Based on the papers about implementing project-based learning courses mentioned above, the main objectives that should be fulfilled by the proposed course have been defined as follows:

1. Integrating wide range of skills and knowledge.

2. Connecting the students' skills and knowledge with the experience, that will help to increase effectiveness of the learning process. 
3. Activating students for lifelong learning.

4. Developing students' ability to communicate and cooperate in a team.

5. Developing students` organizational and time management skills.

\section{Results}

The proposed two semester course purpose is to integrate and develop key competencies of university students through working on various projects in the areas of trade, marketing, economy, tourism etc. As it is inspired by projectbased learning methods, it is important to mention that all project topics should be specified by several enterprises that are interested in this kind of cooperation with university and its students.

According to course structure as shown in fig. 1, students should at first obtain enough relevant theoretical sources in the reseach area and then start to work on concrete solutions or ideas to a given problem by an cooperating enterprise's manager, that expects relevant recommendations suggested by students at the end of the second semester.

Due to the necessary skills and knowledge level of students participating on this projects, the course is recommended especially for students that are in their final year of study. The initial expectation is that this course should effectively combine both theory and practice, so that, in effect, the students can be more enthusiastic about trying something new during their studies. Simultaneously it can result in the enteprises ' opportunity to test students as potential employees, so managers of the cooperating enterprises will be able to choose the right candidates for theirs actual graduate jobs more easily. The whole process flow of the proposed course is shown in fig. 1 .

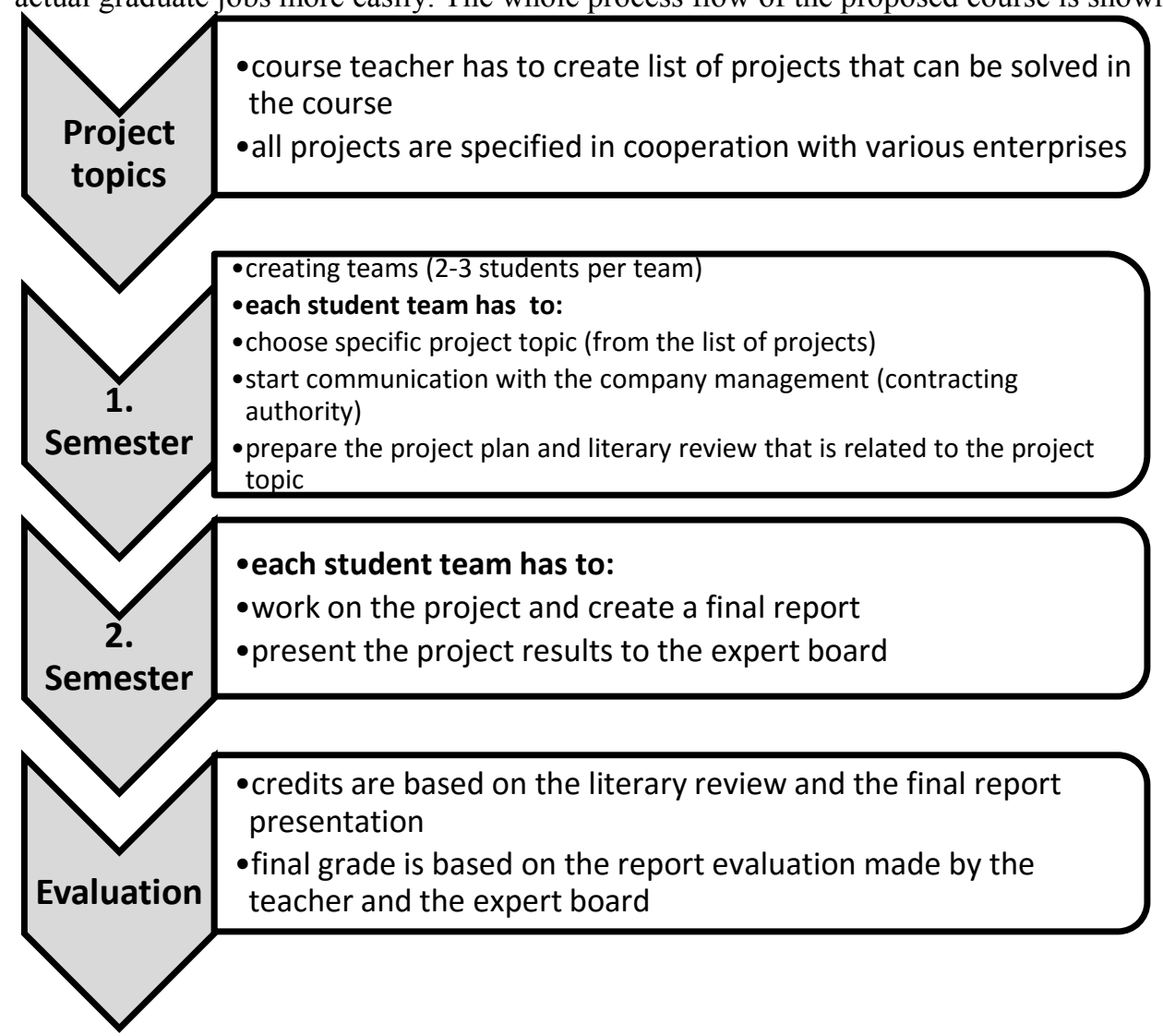

Figure 1. The proposed project-based learning course structure (Source: Author).

\subsection{Recommended project topics}

Projects solving should develop the students' ability to apply their theoretical knowledge on specific, practical and actual problems from their fields of study, so in the case of business and economics schools, the projects can be focused on the following topics:

1. Marketing research,

2. Economic analysis,

3. Data mining,

4. Financial analysis,

5. Event management,

6. Marketing mix,

7. Marketing communication. 


\subsection{Projects evaluation}

As proposed in fig. 1, the first semester of the course would be evaluated with a credit (based on quality project plan and literary review made by all teams), while the second semester is evaluated with both credit and examination. Students will receive credits for presenting the final report to the expert board (which consists for example of managers from the cooperating enterprises). Final report, respectively project documentation, which is the main course output, should contain relevant recommendations for cooperating enterprises how to solve concrete problems in accordance with the aim of the project.

Final grade for each team should be based on criteria defined by course teacher at the beginning of the first semester. The main criteria may be defined as follows:

1. Level of target achievement,

2. Level of the final presentation,

3. Level of literary review,

4. Level of final report,

5. The cooperating enterprise's satisfaction with the final report and results.

\section{Conclusions}

The aim of this paper is to describe the project-based learning method draft, that could be relevant factor in developing students' key competencies such as problem solving, communication, creativity or leadership. Formulated method should be considered especially by university for business and economics.

The main purpose of the proposed two semesters course is to integrate and develop competencies of each student through working on specific projects in the various areas, for example trade, economics, marketing or tourism. Student teams must prepare theoretical and practical solution of the given project, so in the process of working on the topic they can develop their practical skills in a s area. Defined course has been inspired by project-based learning methods, so all projects for students' teams should be specified in cooperation with various enterprises that are interested in this kind of cooperation with concrete university and its students.

As stated in the proposed course structure, students should at first obtain enough relevant theoretical sources in the project area and then start to work on concrete solutions to a given problem or case study by an specific enterprise. At the end of the course, managers involved in the cooperation on the project will expect students' relevant recommendations or solution in the final report. The main expectation is that this course should combine both theory and practice, so that, in effect, the students' skills could be improved more faster and effectively than by regular teaching methods.

\section{References}

1. M. Armstrong, Armstrong's handbook of human resource management practice. 13th Edition (Kogan Page, Philadelphia, 2011).

2. H. Belz, M. Siegrist, Kličcové kompetence a jejich rozvijení (Portál, Praha, 2001).

3. T Weiss, S. Kolberg, Coaching competencies and corporate leadership (CRC Press, Florida, 2003).

4. G. Debling, The employment department/training agency standards programme and NVQs: Implications for education. In J.W. Bruce (Ed.), Competency Based Education and Training (The Falmer Press, London, 1989).

5. M. Hay, Business schools: A new sense of purpose. Journal of Management Development, 27(4), 371-378 (2008).

6. E. Anderson, B. Schiano, Teaching with cases: A practical guide (Harvard Business School Publishing, Boston, 2014).

7. A. Avramenko, Enhancing students' employability through business simulation. Education and Training, 54(5), 355-367 (2012).

8. S.R. Tiwari, L. Nafees, O. Krishnan, Simulation as a pedagogical tool: Measurement of impact on perceived effective learning. The International Journal of Management Education, 12(3), 260-270 (2014).

9. W.N. Bender, Project-based learning: Differentiating instruction for the 21st centrury (Corwin Press, Thousand Oaks, 2012).

10. M. Slavík, Vysokoškolská pedagogika pro odborné vzděláváni (Grada, Praha, 2012).

11. J. Atkinson, Developing teams through project-based learning (Gower Publishing, Hampshire, 2001).

12. J. Allen, Measuring competencies of higher education graduates. New Directions for Institutional Research, 126, 49-59 (2005).

13. W.M. Krompf, Identify core competencies for job success (Association for Talent Development, Alexandria, VA, USA, 2007).

14. R. Maltese, Project based learning: 25 projects for 21st century learning (Dog Ear Publishing, Indianapolis, 2012).

15. M.R. Weber, D.A. Finley, A. Crawford, D. Rivera Jr., An exploratory study identifying soft skill competencies in entry-level managers. Tourism \& Hospitality Research, 9(4), 353-361 (2009). 